\title{
INTEGRATION OF LEAN AND GREEN MANUFACTURING TO SUSTAINABILITY IMPROVING AT PT. TEXTILE JAYA GEMILANG
}

\author{
Rony Prabowo*) \\ ${ }^{*}$ Industrial Engineering Department, Faculty of Industrial Technology \\ Institut Teknologi Adi Tama Surabaya (ITATS) \\ email : rony.prabowo@itats.ac.id
}

\begin{abstract}
PT. Textile Jaya Gemilang is a textile company that has a cotton fabric finishing unit. In the identification carried out the company still produces waste and has not yet carried out an environmentally friendly process. Therefore efforts are needed to identify waste in the process of finishing woven fabrics to make the process environmentally friendly by considering the level of eco efficiency and eco costs to determine the proposed process that is environmentally friendly. This research includes steps such as analyzing value stream mapping to find out activities that have value added and categorized as NVA. Furthermore, measurements of environmental impacts were carried out with LCA (Life Cycle Analyzing) and then gave a proposal to provide a proposed process with the $6 \mathrm{R}$ approach (reuse, reduce, recycle, remanufacturing, recovery and redesign) in the process of finishing cotton cloth obtained by waste, namely in appropriate processing, defect and waiting time. The results of the Life Cycle Assessment showed results for a process of 248.76 pt, for Life Cycle Impact Assessment Damage Category Human Health of 4.8813 DAILY, Damage Category Ecosystem Quality of 310,000 PDF * m2yr and for Damage Category Resources 1615,646 MJ surplus . Eco cost is Rp. 608,425,018.2. Proposed environmentally friendly process by raising the level of green manufacturing to recycling and reuse.
\end{abstract}

Keywords: sustainability, waste, cost, eco, value.

\section{INTRODUCTION}

The development of the industrial sector has had a positive impact on state revenues but also has a negative impact on environmental problems caused by industrial waste and excessive use of natural resources. The industrial sector in the last fifty years uses half of the world's total energy (Dornfield, 2014;
Gara-Reyes, 2015; Prabowo, 2013). In connection with the scarcity of natural resources, issues of global warming, management of waste, and government regulations regarding the environment have begun to be tightened and will be a challenge for the industrial world, especially the manufacturing industry in addition to competition and changes in a very fast and dynamic business environment. Sustainability Manufacturing (SM) is often interpreted as the creation of economically valuable products through processes that minimize negative impacts on the environment, save energy and natural resources, and preserve natural resources and energy to ensure their availability in the future (Amaranti et al, 2017; Dues et al, 2013; Tseng et al, 2013).

To reduce waste and minimize production costs, lean manufacturing method is an effort made by a company to increase production efficiency ( Rinawati and Sari, 2012; Sangwan, 2011). Adding value to products (value added) such as disposal, excessive activity, does not provide added value. Lean manufacturing is a systematic approach to identifying and eliminating waste through continuous improvement, in order to create a smooth flow of production processes with fast lead time and little waste (Javal et al, 2010; Prabowo, 2017; Rinawati et al, 2013). To overcome the impact on environmental problems caused by industry, a concept was created that aims to tackle environmental problems. This company has a vision to become a leading textile company in Indonesia. To support the long-term and shortterm goals of the company, this study can be considered by the management to improve sustainable development by applying related concepts.

Sustainability Manufacturing with the approach of supporting methods of lean manufacturing and green manufacturing as 
"the creation of economically valuable products through processes that minimize negative impacts on the environment, save energy and natural resources, and preserve SM aimed at achieving sustainable development, this has been stated by the world commission relating to environment and development which means that sustainability development as development meets current needs without compromising the ability of future generations to meet the needs of the company itself (Gasper, 2017; Liker, 2006). Lean is a process management philosophy originating from the Toyota Production System (TPS) described in detail by Taiichi Onho and Shiego Shingo. Lean itself has a focus on reducing waste to increase value to customers as a whole. Lean is also defined as a strategy to achieve sustainable development results through reducing waste from all manufacturing processes or systems in a company (Carvalho et al, 2011; Tseng et al, 2013). Green Manufacturing (GM) is a manufacturing practice that is safe for the environment every phase of its journey (Rinawati and Sari, 2012; Rinawati et al, 2013,; Sangwan, 2011).

\section{METHODOLOGY}

In the steps that must be done in this study as well as identifying problems, conducting literature studies, collecting and processing data and analyzing the results of a study. and finally is to conclude the results of a research that has been done. The following is the research method flowchart used in this study in Figure 1.

\section{Data Collecting}

At this stage data will be collected and information needed in the preparation of this research report. The data to be processed will later be processed with appropriate methods in an effort to achieve the objectives set in the previous stage. As for what should be done Primary data needed, namely regarding data on work activities include the flow of raw material information, and the flow of natural resources and energy to ensure their availability in the future (Carvalho et al, 2011; Heier et al, 2007). In the implementation of

information about waste. Next is the data regarding the cycle time process in the cotton fabric production process at PT. Textile Jaya Gemilang. Secondary data includes a general description of the company, a brief history of the company, specifications of the machine and company, energy requirements, raw materials and auxiliaries, types of products produced, historical data on demand, production, and waste that occurred in the past six months.

\section{Raw Materials, Auxiliary Materials and Energy Use}

The main raw material in the finishing process is fabric processed products produced from the weaving division. Furthermore, the weaving process will be finalized. In this process, it requires several mixtures to get the fabric according to the customer's request. The following are the raw materials for the finishing process shown in Table 1.

Information Flow Regarding Waste Management

Information flow regarding waste handling at PT. Textile Jaya Gemilangis a standard that has been made and established by the company. The following is information about handling waste in the company (Table 2).

Data processing carried out in this study includes lean manufacturing consisting of several techniques or tools that exist in lean manufacturing concepts including making current value stream mapping, identifying waste, doing detailed mapping with VALSAT, and designing future value stream mapping. The green manufacturing method will process data that has been collected by processing life cycle assessment then processing Eco-cost per value ratio, and identifying $6 \mathrm{R}$ (reuse, recover, redesign, remanufacturing, reuse, reduce). 


\section{Tibuana}

Journal of applied Industrial Engineering-University of PGRI Adi Buana

p-ISSN 2622-2027

$e$-ISSN 2622-2035

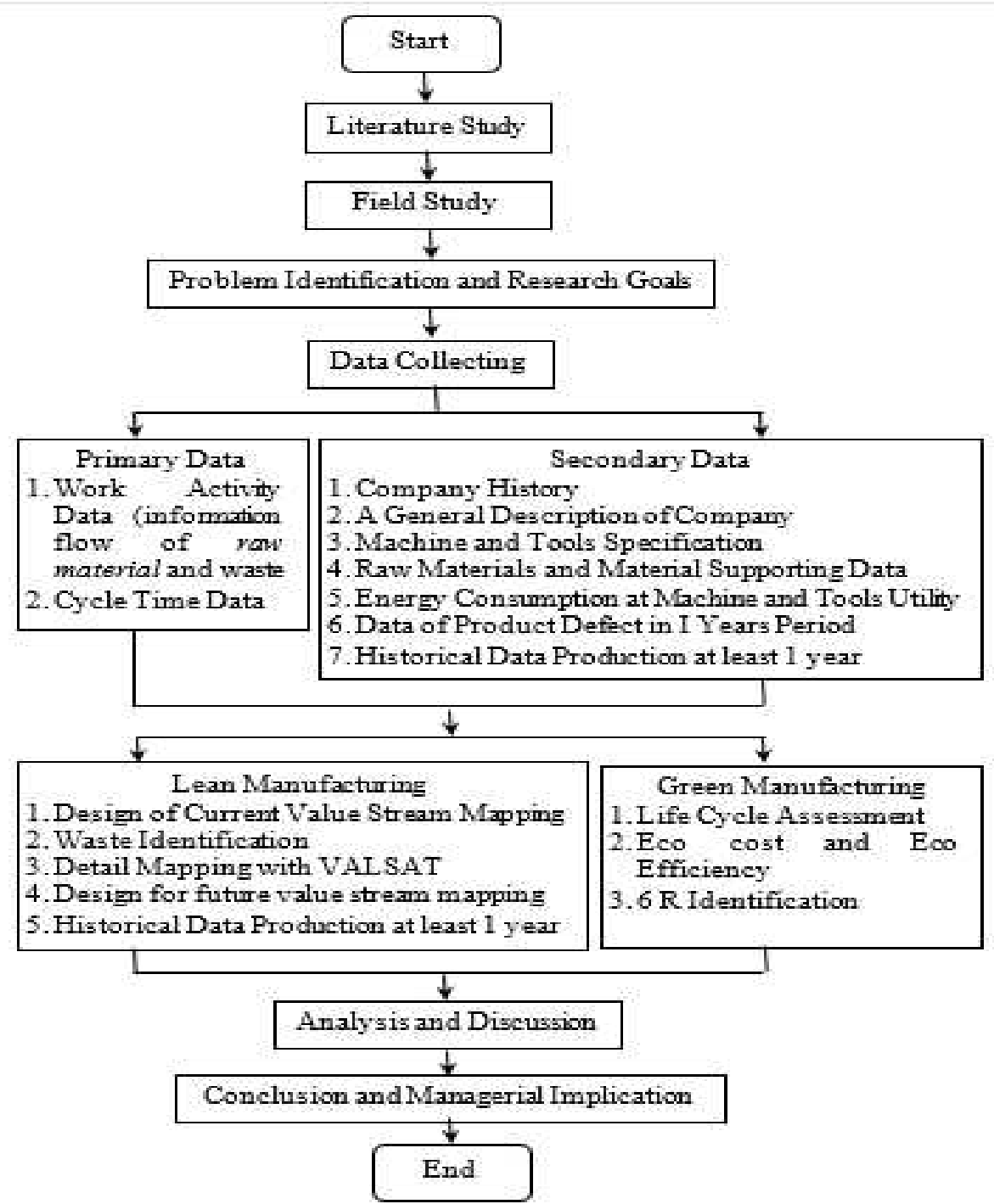

Figure 1. ResearchMethodology 
Table 1 Grouping of Voice of Customer Attributes

\begin{tabular}{|c|c|c|c|c|}
\hline No. & $\begin{array}{c}\text { Raw / Auxiliary } \\
\text { Materials }\end{array}$ & $\begin{array}{c}\text { Capacity } \\
\text { (Volume/Time) } \\
\text { Raw Materials } \\
50.000 \mathrm{~m} / \mathrm{bl} \\
\text { Auxiliary Material }\end{array}$ & Physically & Warehouse \\
\hline 1. & Ecowet & $500 \mathrm{~kg} / \mathrm{bl}$ & Liquid & Plastic Drum \\
\hline 2. & Protase & $1200 \mathrm{~kg} / \mathrm{bl}$ & Brown Liquid & Plastic Drum \\
\hline 3. & $\mathrm{H}_{2} \mathrm{O}_{2}$ & $500 \mathrm{~kg} / \mathrm{bl}$ & Clearly Liquid & Plastic Drum \\
\hline 4. & Leocophor & $400 \mathrm{~kg} / \mathrm{bl}$ & Violet Liquid & Plastic Drum \\
\hline 5. & Sodium carbonate & $700 \mathrm{~kg} / \mathrm{bl}$ & Powder & Plastic Drum \\
\hline 6. & Sodium hypochlorid & $3500 \mathrm{~kg} / \mathrm{bl}$ & Yellow Liquid & Plastic Drum \\
\hline 7. & Natrium thiosulfat & $20 \mathrm{~kg} / \mathrm{bl}$ & Powder Crystal & Plastic bag \\
\hline 8. & Sodium hidrosulfat & $10 \mathrm{~kg} / \mathrm{bl}$ & Powder & Zink Drum \\
\hline 9. & Caustic soda flake & $1700 \mathrm{~kg} / \mathrm{bl}$ & Flake & Plastic bag \\
\hline 10. & Water glass & $125 \mathrm{~kg} / \mathrm{bl}$ & - & Zink Drum \\
\hline 11. & Oxalid Acid & $75 \mathrm{~kg} / \mathrm{bl}$ & Crystal & Plastic bag \\
\hline 12. & Prolovet & $100 \mathrm{~kg} / \mathrm{bl}$ & Gel & Plastic Drum \\
\hline 13. & Salt & $6500 \mathrm{~kg} / \mathrm{bl}$ & Solid & Plastic bag \\
\hline 14. & Caustic water soda & $27.500 \mathrm{~kg} / \mathrm{bl}$ & Liquid & Tank Drum \\
\hline
\end{tabular}

Table 2. Company Waste Handling

No. Waste Classification Waste Handling

1. Gas waste and noise come from the use of fuel in the boiler to produce steam, and noise comes from production machinery.

2. Solid waste

a. The results of the production waste include, the remainder of the defective fabric, the remaining feathered fabric.

b. Wastewater from IPAL from sediment.

3. Liquid waste

Liquid waste comes from utilities (Kettle, cooling tower, softener), process units (kier kettle, neutralization mangle, mercerization, jigger), cooling of machines, workshops (oil spills).
For exhaust gases managed by sprayed water and fly ash will settle in water, while for noise, employees are required to use earplugs, for sound on the wall of the blower there is a silencer and shade trees are planted in the factory environment.

a. The remaining waste of this production is collected and selected according to its type. Next, collectors are collected every two weeks.

b. The sludge in the reservoir is lifted and then dried, for the use of it, while only reducing the soil in the factory.

Handling is flowed to the control basin through sewerage (separate from rainwater). From the tub of control enter the equalization bath for liquid waste from cotton and rayon. After the liquid waste becomes homogeneous or uniform, it is then channeled to the process vessel for the coagulation and flocculation process. The coagulation used was ferosulfate and lime. Flocculation is a physical process because floc-forming will form, which will easily settle in the sedimentation bath. Clear waste water is flowed into the cooling spray bath so that 
$\mathrm{pH}$ and temperature become normal. Then the water is flowed into the reservoir and then pumped into the filter tub to be filtered and flowed into the environment.

\section{Data Processing With Lean Manufacturing Method}

Analysis using Value Stream Mapping (VSM) obtained value added and non-value added activities

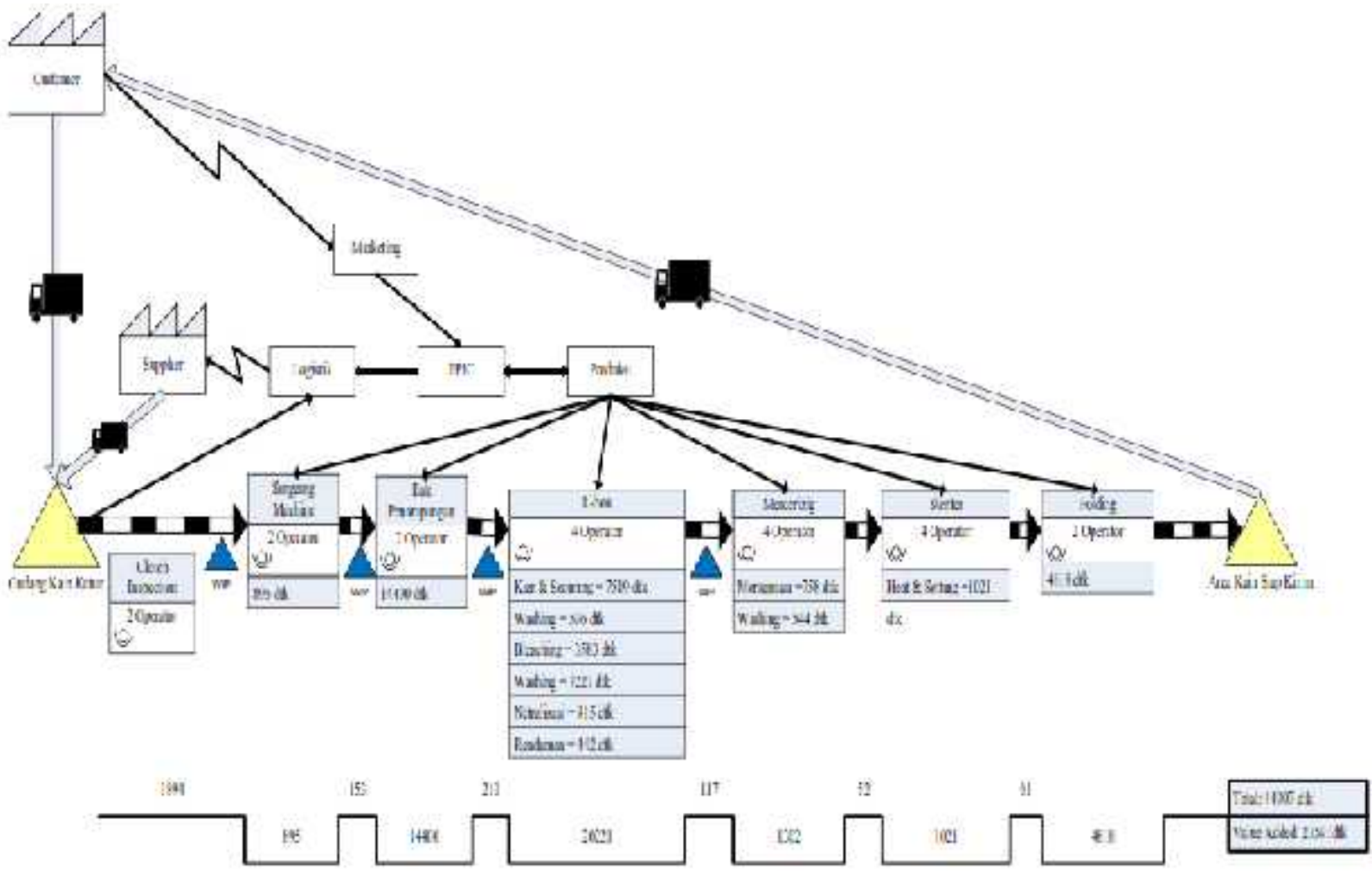

Figure 2 Current Value Stream Mapping Cotton Fabric Finishing Process

Table 3. Weighting Detail Mapping

\begin{tabular}{lcc}
\hline \multicolumn{1}{c}{ Detail Mapping } & Weight & Rank \\
\hline Process Activity Mapping & 47,625 & 1 \\
Supply Chain Response & 33,000 & 2 \\
Matrix & & \\
Product Variety Funnel & 6,875 & 6 \\
Quality Filter Mapping & 23,000 & 3 \\
Demand Amplification & 18,000 & 4 \\
Mapping & & \\
Decision Point Analysis & 11,875 & 5 \\
Physical Structure & 1,125 & 6
\end{tabular}

18 | TiBuana, Vol. 2, No.2, 2019 
Table 4. Recapitulation of Process Activity Mapping Cotton Fabric Finishing Process

\begin{tabular}{|l|c|c|c|}
\hline \multicolumn{1}{|c|}{ Activity } & Total & $\begin{array}{c}\text { Time } \\
\text { (sekon) }\end{array}$ & $\begin{array}{c}\text { Prosentase } \\
(\%)\end{array}$ \\
\hline Operation & 17 & 42613 & 41,63 \\
\hline Transportation & 6 & 264 & 4,09 \\
\hline Delay & 2 & 1860 & 52,12 \\
\hline Inspect & 1 & 45 & 1,2 \\
\hline Storage & 2 & 125 & 0,88 \\
\hline Total & 28 & 44907 & 100 \\
\hline Classification & Total & Time & Prosentase \\
\hline & & (sekon) & $(\%)$ \\
\hline VA & 12 & 27591 & 61,44 \\
\hline NVA & 5 & 2165 & 4,82 \\
\hline NNVA & 11 & 15151 & 33,74 \\
\hline Total & 28 & 44907 & 100 \\
\hline
\end{tabular}

\section{Supply Chain Response Matrix}

Based on the detailed mapping of the VALSAT table, the supply chain response matrix is the chosen mapping tool to analyze the production needs of cotton cloth finishing. Tools chosen to analyze the Master Production Schedule (MPS). This tool was chosen to schedule production quantities.

Table 5. Draft of Master Production Schedule

\begin{tabular}{ccccccccccccc}
\hline Periode & 1 & 2 & 3 & 4 & 5 & 6 & 7 & 8 & 9 & 10 & 11 \\
\hline $\begin{array}{c}\text { Demand } \\
\text { Actual }\end{array}$ & 42000 & 45000 & 50000 & 50000 & 45000 & 50000 & 45000 & 50000 & 45000 & 47000 & 50000 & 50000 \\
$\begin{array}{c}\text { Projected } \\
\text { Available }\end{array}$ & 8000 & 15173 & 17346 & 24519 & 26692 & 28865 & 36038 & 38211 & 45384 & 50557 & 557 & 2730 \\
$\quad$ MPS & 0 & 52173 & 52173 & 52173 & 52173 & 52173 & 52173 & 52173 & 52173 & 52173 & 0 & 52173 \\
\hline
\end{tabular}

\section{Quality Amplification Mapping}

Table 6. Recapitulation Results of Disability of Cotton Fabric Products

\begin{tabular}{llcc}
\hline Code & \multicolumn{1}{c}{ Kinds of Failure } & $\begin{array}{c}\text { Frequency } \\
\text { Index }\end{array}$ & Probability \\
\hline 014 & Clip on the wear flashlight machine & 3 & 0,46 \\
022 & Mixing drugs for finishing cloth & 3 & 0,17 \\
023 & Roll clamps on fabric are not balanced & 2 & 0,54 \\
024 & Rush to put cloth on the machine & 2 & 0,33 \\
025 & Does not check the balance of the roll clamp & 3 & 0,37 \\
026 & Neglect to replace the worn stenter clamp clip & 3 & 0,08 \\
027 & Neglecting to monitor the embers on the singer machine & 3 & 0,17 \\
028 & The engine is old & 1 & 0,83 \\
029 & The extinguisher valve is worn out & 3 & 0,46 \\
030 & Turn too slow & 4 & 0,25 \\
031 & Turn too fast & 4 & 0,42 \\
032 & The type of enzyme used is not good & 3 & 0,25 \\
033 & Mixing is not careful & 3 & 0,46
\end{tabular}

Source : Internal Corporate 2018 (processed) 


\section{Tibuana}

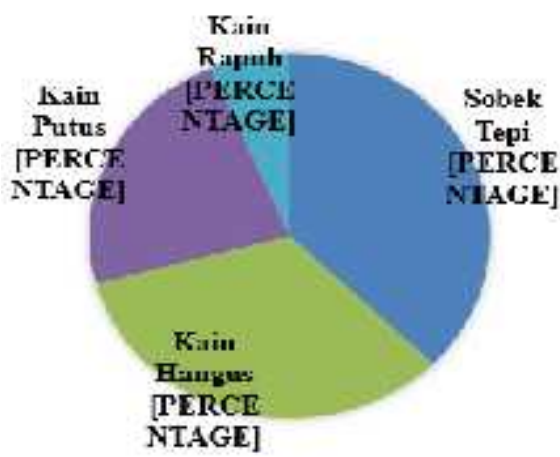

Figure 3 Quality Amplification Mapping Diagram

Based on Table 6 above, the biggest probability of causing defects in cotton cloth products is the type of edge tear defects with a probability of 0.86 . The following are the results of the root causes of problems in the type of product defects that are torn from the edge seen from the basic event of using the FTA.

Based on the results of field observations and discussions with several parties who are competent towards the textile manufacturing process, the causes of edge tearing include: (1) clip the wear stenter machine, (2) roll clamps on the non-swell, (3) roll not clamp the fabric perfectly , (4) hastily installing cloth on the machine, not checking the balance of the clamping roll, and (5) neglecting to replace the worn stanter clamp clip.

In Table 5 lot size is 52173 meters, the total production that can be done is $521730 \mathrm{~m}$ in one year. This yield is smaller than the current production of the company with total production in one year, which is $568948 \mathrm{~m}$. implemented green manufacturing in the production process.
Difference from current production and at the time of application of the MPS is equal to $47218 \mathrm{~m}$.

\section{RESULTS AND DISCUSSION}

Analysis of Lean Manufacturing Method Results

Based on processing with Process Activity Mapping (PAM), activities obtained in the process of finishing cotton cloth include value added, non value added, and necessary non value added activities (Table 7).

\section{Green Manufacturing Analysis}

Based on green manufacturing identification on the object under study aims to analyze the extent to which the company implements green manufacturing in the production process. The researcher conducted a green manufacturing identification on the object under study aimed at analyzing the extent to which the company 


\section{Tibuana}

Journal of applied Industrial Engineering-University of PGRI Adi Buana

p-ISSN 2622-2027

$e$-ISSN 2622-2035

Table 7 Value Stream Analysis Tools Cotton Fabric Finishing Process

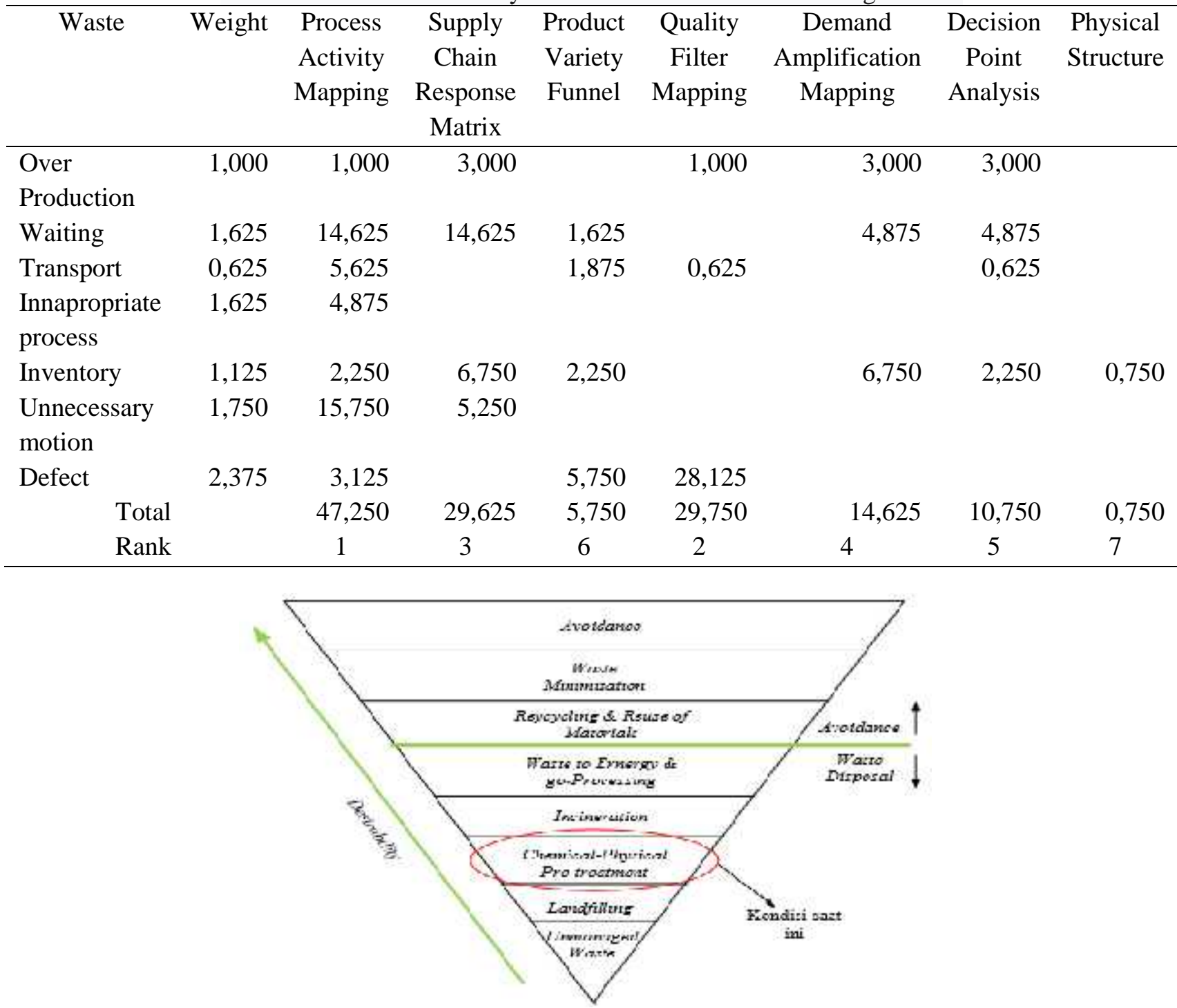

Figure 4. The Concept of the Green Manufacturing Pyramid of the Company

From the identification of the green manufacturing pyramid concept, the condition of the company has not reached the avoidance level or applied the green concept as a whole. This is indicated by the company's policy on waste management which includes unmanaged waste, landfilling, and chemical-physical pretreatment.

\section{Life Cycle Assessment (LCA) Analysis}

Based on the identification carried out on the company the results of processing cycle cycle assessment by using the help of simapro 8.0 software with the eco-indicator $99(\mathrm{H})$ method, results were obtained in the process contribution, characterization, and damage assessment as follows.

Table 8. Grouping Damage Assessment

\begin{tabular}{lll}
\hline Damage Category & \multicolumn{1}{c}{ Unit } & \multicolumn{1}{c}{ Cotton } \\
\hline Human health & DALY & 4,881337 \\
Ecosystem quality & PDF*m2yr & 310,000 \\
Resources & MJ surplus & 1615,646 \\
\hline
\end{tabular}

TiBuana, Vol.2, No.2, 2019|21 


\section{Tibuana}

Journal of applied Industrial Engineering-University of PGRI Adi Buana

p-ISSN 2622-2027

$e$-ISSN 2622-2035

The results of the software processing simapro 8.0 resulted in the impact of damage to human health 4,88133 DALY which means that 4,8813 years of healthy life were lost from someone The resulting Ecosystem quality is $310,0000 \mathrm{PDF} * \mathrm{~m} 2 \mathrm{yr}$, meaning that the ecosystem or species damage covers an area of $310,0000 \mathrm{~m}^{2}$ in one year. As for resources, it produces an impact of 1615,646 MJ sueplus which means the amount of basic energy needed to extract natural resources. Based on the identification of life cycle assessment and life cycle impact assessment, the eco-cost costs obtained from the finishing process of cotton fabrics are as follows in Table 9.
Based on the results of the eco-cost calculation above, the results for the cost of handling environmental impacts are Rp. $608,425,018.2$. From the identification of the process contribution above based on the energy input and output of the cotton fabric finishing process, it can be seen that the total process of finishing cotton cloth has an impact of $248.76 \mathrm{Pt}$. The unit unit in the simapro software namely $\mathrm{Pt}$ (point) scale $1 \mathrm{Pt}$ represents one thousandth of the annual environmental load for one average population in Europe.

Table 9. Results of Attractive Category Variables

\begin{tabular}{lllllr}
\hline Damage Category & \multicolumn{1}{c}{ Unit } & Cotton & $\begin{array}{c}\text { Conversion } \\
\text { Factor }\end{array}$ & $\begin{array}{r}\text { Conversion } \\
(\mathrm{Rp})\end{array}$ & $\begin{array}{r}\text { Eco Cost } \\
(\mathrm{Rp})\end{array}$ \\
\hline Human Health & DALY & 0.488134 & 36121.89 & 16843.4 & 608416589.7 \\
$\begin{array}{l}\text { Ecosystem } \\
\text { Quality }\end{array}$ & PDF*m2yr $^{*} 0.3100$ & 0.43 & & 7310.04862 \\
$\begin{array}{l}\text { Resources } \\
\text { Total }\end{array}$ & MJ surplus & 16.16 & 0.07 & & \\
\hline
\end{tabular}

Table 10. Process Contribution in Cotton Fabric Finishing Process

\begin{tabular}{|c|c|c|c|c|}
\hline \multirow[t]{3}{*}{ No. } & Process & Project & Unit & Total \\
\hline & Total of All Processes & & $\mathrm{Pt}$ & 248.76 \\
\hline & Remaining Processes & & $\mathrm{Pt}$ & 3.17665 \\
\hline 1. & $\begin{array}{l}\text { Electricity, Anthracite coal at power } \\
\text { plant/RNA }\end{array}$ & USLCI & $\mathrm{Pt}$ & 174.624 \\
\hline 2. & $\begin{array}{l}\text { Anthracite coal, combusted in industrial } \\
\text { boiler/RNA }\end{array}$ & USLCI & $\mathrm{Pt}$ & 50.0246 \\
\hline 3. & Anthracite coal, at mine/RNA & USLCI & $\mathrm{Pt}$ & 15.5364 \\
\hline 4. & Crude oil, at production/RNA & USLCI & $\mathrm{Pt}$ & 3.05413 \\
\hline 5. & $\begin{array}{l}\text { Electricity, high voltage (ASCC), electricity } \\
\text { production, natural gas, combined cycle power } \\
\text { plant/Alloc Def, S }\end{array}$ & $\begin{array}{l}\text { Ecoinvent 3- } \\
\text { allocation } \\
\text { default system }\end{array}$ & $\mathrm{Pt}$ & 1.17813 \\
\hline 6. & $\begin{array}{l}\text { Transport, combination truck, diesel } \\
\text { powered/US }\end{array}$ & USLCI & $\mathrm{Pt}$ & 1.16596 \\
\hline
\end{tabular}

Proposed Improvement Based on Lean Manufacturing Integration with Green Manufacturing

Based on the identification of activity mapping process, waste is obtained from activities that do not provide non value added to the process of finishing cotton fabrics. These activities will then be grouped for improvement with the 6R approach (reuse, reduce, recycle, remanufacturing, recover, redesign). The following are proposed 


\section{Tibuana \\ Journal of applied Industrial Engineering-University of PGRI Adi Buana}

p-ISSN 2622-2027

$e$-ISSN 2622-2035

improvements based on the PAM tools mapping.

1. Reuse

Based on the PAM, the activity awaiting hot steam filling will be repaired by utilizing condensate treated waste for feed on the boiler machine. Machines that produce condensate waste are mercerizing machines, 1-boxes, and stents. According to the finishing expert at the company, the waste from the machine can produce $20 \%$ condensate, this means that the waste can be used for boiler feed so that it can reduce $20 \%$ of the total time to wait for hot steam. Then the waiting time is obtained:

1800 seconds $X 20 \%=340$ seconds

1800 seconds -340 seconds $=1440$ seconds

So the time to wait for hot steam is reduced to 1440 seconds.

The next activity to be repaired is to fill the water in the reservoir for the starch removal process. Repair is done by utilizing cooling water on the singeing machine. According to the cloth water cooling finishing expert on the singeing machine it is still in a clean condition so that it can be directly flowed to the starch removal basin. Substance mixing activity for the needs of the L-box machine utilizing bleaching laundry wastewater is accommodated for reuse in the scouring process. According to cloth finishing experts, this can be done, but management policies that have not been made suitable SOPs.

\section{Redesign}

a. Redesigning the pipe to the boiler machine to produce condensate waste from the mercerizing machine, 1-box and stenter. After discussions with finishing experts at the company, adding pipes can be done by adding several pumps to the condensate feed to the boiler.

b. Designing to utilize residual water from the singeing engine coolant for further flow to the reservoir in the starch removal process. By adding pipes to drain the water, filling the water can utilize the remaining singeing engine cooling water and

\section{CONCLUSION}

From the analysis of the results of research that has been carried out related to the implementation of lean and green manufacturing carried out at PT. Textile Jaya Gemilangconcludes as follows:

1. Based on the identification with the lean manufacturing concept that is carried out, it can be concluded that the waste that occurs in the finishing process of cotton fabrics includes waste delays (waiting time), process, and defects. Waste is obtained through VALSAT table analysis which produces the highest ranking mapping tools, namely process activity mapping with bob 47,625, quality filter mapping with a weight of 33,00 , and supply chain response matrix weighing 23,00.

2. Based on an analysis of the level of ecoefficacy by using the Life Cycle Assessment approach, the cotton fabric finishing process was obtained, which was equal to $248.76 \mathrm{Pt}$. for life cycle impact assessment which produces three human health category damage of 4.8813 DALY, damage category ecosystem damage by $310,000 \mathrm{PDF} * \mathrm{~m} 2 \mathrm{yr}$, and for damage category resources $1615,646 \mathrm{MJ}$ surplus. With eco-cost costs of Rp. 608,425,018.2.

3 . Based on the Green Manufacturing pyramid concept, the proposal for an environmentally friendly process is to increase the level of the company from the 


\section{Tibuana}

Journal of applied Industrial Engineering-University of PGRI Adi Buana

p-ISSN 2622-2027

$e$-ISSN 2622-2035

level of Chemical-Pretreatment PreTreatment to the level of Reycycling and Reuse of Materials. The proposal was made by utilizing condensate waste as boiler feed, the rest of the sigeing engine cooling water which was reused for the starch removal process, utilizing the remaining bleaching laundry water for the scouring process, and engineering for engine components that could still be used.

\section{Managerial Implication}

The managerial implications that are expected with the existence of this research to companies that are the object of research are as follows:

1. The occurrence of increased sustainability in companies, where companies must be more committed to handling waste that occurs in the production process.

2. The company pays more attention to the impacts produced by the production process which can have a direct impact on the environment by utilizing waste to be reprocessed so that it can be used as a waste for process needs.

3. The company will consider more the cost of minimizing waste and handling waste.

\section{REFERENCES}

1. Amaranti R., Irianto D., Govindaraju R. (2017). Green ManufacturingKajian Literatur, Seminar dan Konferensi Nasional IDEC 2017, 171-181.

2. Carvalho, H., Duarte, S., Cruz-Machado, V. (2011).Lean, agile, resilient and green: divergences and synergies. Int. J. Lean Six Sigma, 2(2): 151-179.

3. David A. Dornfeld (Ed.). (2013).Green Manufacturing : Fundamentals and Applications. New York: Springer Science Business Media New York.

4. Dües, C.M., Tan, K.M., Lim, M. (2013).Green as the new Lean: how to use Lean practices as a catalys to greening your supply chain. Journal of Cleaner Production, 40: 93-100.

5. Dornfeld, D. A. (2014). Moving Towards Green and Sustainable Manufacturing. International Journal of Precision
Engineering and Manufacturing-Green Technology, 1(1), 63-66.

6. Garza-Reyes, J.A. (2015). Green lean and the need for Six Sigma. Int. J. Lean Six Sigma, 6(3): 226-248.

7. Gaspersz, V. (2012).Manajemen Produktivitas Total. PT. Gramedia Pustaka Utama, Jakarta.

8. Heizer, Jay H., Render, Barry. (2007).Operation Management: Student Lecture Guide. New Jersey: Pearson Prentice Hall.

9. Jayal, A. D., Badurdeen, F., Jr, O. W. D., \& Jawahir, I. S. (2010). Sustainable manufacturing : Modeling and optimization challenges at the product, process, and system levels. CIRP Journal of Manufacturing Science and Technology, 2, 144-152.

10. Liker, K. Jeffrey. (2006). The Toyota Way. Erlangga. Jakarta.

11. Luglieti R. (2017).Life Cycle Assessment Tool Implemented in Household Refrigeration Industry: Journal of Cleaner Production, 40: 101-111.

12. Prabowo R. (2013).Analisa Pemilihan Supplier Polyurethan dengan Vendor Performance Indicator Berbasis Quality, Cost, Delivery, Flexibility dan Responsiveness di PT. Sinar Foam Jaya Surabaya. Institut Teknologi Adhi Tama Surabaya.

13. Prabowo R. (2017). Pengendalian Persediaan Bahan Baku Oli Untuk Mesin Diesel Tipe G4J-801, G5J-801 dan G7J-801 di PT. Hansan Asembling-Malang. PROZIMA (Productivity, Optimization and Manufacturing System Engineering). Apr 6;1(1):33-43.

14. Rinawati, D, Sari, D. (2012). Pengukuran Tingkat Eko-efisiensi Menggunakan Life Cycle Assessment untuk Menciptakan Sustainable Production di Industri Kecil Menengah Batik. JTI, 14, No 2.

15. Rinawati, D, Sari, D, Nugroho, S. (2013). Pengelolaan Produksi Pendekatan Lean And Green Untuk Menuju Industri Batik Yang Berkelanjutan (Studi Kasus Di Ukm Batik Puspa Kencana). Jurnal Undip, VIII, No 1. 


\section{Tibuana}

Journal of applied Industrial Engineering-University of PGRI Adi Buana

p-ISSN 2622-2027

$e$-ISSN 2622-2035

16. Sangwan, K. S., \& Mittal, V. K. (2015). A bibliometric analysis of green manufacturing and similar frameworks. Management of Environmental Quality: An International Journal, 26(4), 566-587.

17. Sangwan, K. S. (2011).Development of a multi criteria decision model for justification of green manufacturing systems. International Journal Green Economics, 5(3), 285-305.

18. Tseng, M., Shun, A., Chiu, F., Tan, R. R., \& Siriban-manalang, A. B. (2013).Sustainable consumption and production for Asia : sustainability through green design and practice. Journal of Cleaner Production, 40, 1-5.

19. Wakjira W., Altenbach H., \& Ramulu j. (2018). Optimization of manufacturing sustainability in the Ethiopian industries. Journal of Cleaner Production, 40: 41-52. 